\title{
Review and Comparison of Performance Measurement Systems
}

\author{
Michaela Striteska and Marketa Spickova \\ University of Pardubice, Faculty of Economics and Administration, Pardubice, Czech Republic
}

\begin{abstract}
The main aim of this paper is to analyse, compare and summarize the strong and weak points of the most widely cited performance measurement systems on the basis of literature review. Specifically, the literature review was conducted with the goal to searching papers and case studies that are directly or indirectly concerned with performance measurement systems or models. Based on different background, characteristics and premises, comprehensive view on strengths and weaknesses of each system in the aspect of performance measurement is provided. The performed analysis presents that every conceptual performance measurement system has a clear theoretical background, but seldom provides detailed guidance on how a company should design its unique model. Therefore, it is necessary to conduct further research focused on fulfillment of the company specific measurement needs, particularly at the operational level.
\end{abstract}

Keywords: Performance management, Performance measurement system, Strategic performance measurement.

\section{Introduction}

Increasing competition, changing external demand as well as roles of business forcing the enterprises to examine and improve their strategies and management systems. The first condition to improve, and ultimately to achieve, business excellence, is to develop and implement a system for performance measurement (hereafter PM) (Kanji, 2002). Hence the particular attention is given to strategic management and performance measurement issues.

The environment in which the organizations nowadays operate is dynamic and success depends upon meeting the changing needs of all stakeholders, an organization cannot build a self-centered performance measurement system. The companies need to evaluate performance from an external perspective, listening to customers, suppliers and other stakeholders. In literature as well as in practice we can find a lot of well-established systems providing guidelines for strategic performance measurement and management system development. The various holistic PM systems that try to overcome the shortcomings of traditional measurement systems were developed. They discuss the issue of PM from different perspectives and strive for the best approach. Unfortunately these different approaches have led to numerous definitions of a PM system, and there is little consensus regarding its main components and characteristics (Dumond, 1994). The gap between what are wanted to be measured and what can be measured is the main reason for performance measurement being still so challenging (Meyer 2002).

The aim of this paper is therefore on the basis of literature review investigate and

Copyright (C) 2012 Michaela Striteska and Marketa Spickova. This is an open access article distributed under the Creative Commons Attribution License unported 3.0, which permits unrestricted use, distribution, and reproduction in any medium, provided that original work is properly cited. Contact author: Michaela Striteska E-mail: michaela.striteska@upce.cz 
analyse the strong and weak points of the selected performance measurement and management systems. The literature review was conducted with the main goal to searching case studies (Othman, R. et al. (2006), Nabitz, U. et al. (2001), Yaghoubi, N. M; Bandeii, M; Moloudi, J. (2011), Sadeh, E; Arumugam, V. Ch. (2010), Appelbaum, S. H; Nadeau, D.; Cyr, M. (2008), Hudson, M; Smart, A; Bourne, M. (2001), Calvo-mora, A; Leal, A; Roldan, J. L (2005), Marques, A. I, et al. (2011)) that are related to PM systems or models. First, a brief consideration of the effort of performance management systems adoption is carried out. The performance measurement, but be view as one element of a general management system that comprises many essential components that together form a performance management system. Second, the characteristics and strong and weak points of currently used performance measurement systems are identified and discussed. For the purposes of this paper, 'performance' is related to achieving stakeholder interests. As well as notions system and model are with regard to PM understood as identical terms.

\section{Performance Measurement and Management}

Traditionally, the focus of performance measurement has been on financial measures only. By the late 1980s, studies had shown that historic financial data is not enough to satisfy the PM in the new economy because of the increasing complexity of organizations and the markets in which companies compete (Kennerley, Neely 2002). This is because financial reports are now less indicative of shareholder value. As pointed out by Cumby and Conrod (2001), sustainable shareholder value is instead driven by non-financial factors, such as customer loyalty, employee satisfaction, internal processes, and an organization's innovation. For the Standard and Poor 500, only 10 to 15 percent of market value is captured by traditional accounting measures (Webber, 2000). Hence, nowadays could be seen increasing emphasis on forward-looking non-financial measures (Ittner, Larcker, 2001, Epstein, Manzoni, 1997).

At this point it is necessary to stress that performance measurement and performance management are not the same notions. The literature on performance measurement is much more extensive than the literature on performance management. The second is often used to refer to individual performance management or appraisal schemes. The theme of the performance measurement literature, on the other hand, is preoccupied with the measurement process with less reference to the context within which measurement is carried out. The focus is with the validity of the measurement system rather than how the information will be used to change and improve the way in which services are delivered (Kloot, Martin, 2002). There is little discussion about the quality of performance information and a connection between performance and strategy.

Although much research has been conducted on the issues of performance measurement the definition of performance measurement is still debated $(\mathrm{Wu}, 2009)$. According to Moullin (2007) the most presented PM definition is Neely et al. (2002) "the process of quantifying the efficiency and effectiveness of past actions". This definition stresses effectiveness as well as efficiency, but does not indicate what quantify or why. The explanation that gives better guidance to people involved in PM performance measurement with an emphasis on measurement of value that the organisation deliver to the customers provide Moullin (2003) "PM is evaluating how well organisations are managed and the value they deliver for customers and other stakeholders".

The key idea is: company defines its envisaged performance and outlines how this performance could be measured by formulating performance indicators. This process will show whether the envisaged performance was accomplished and what the cost of it was. After that performance 
management, in broad terms, could be characterized as strategic approach to management, which equips managers, employees and stakeholders at different levels with instruments and techniques. These tools and techniques are utilized by role players to regularly plan, continuously monitor, and periodically measure and review performance of the organization in terms of set indicators and targets for efficiency, effectiveness and impact (Conradie, 2003). In brief, Bititci et al. (1997) define performance management as the process by which the organization integrates its performance with its corporate and functional strategies and objectives. As stated Plant (2006) performance measurement must be viewed as one element of a general management system that comprises many essential components that together form a performance management system.

\section{Performance Management Systems}

Within this context performance measurement system can be characterized according to Kennerley and Neely (2000) as follows:

- The measures used by an organization have to provide a 'balanced' picture of the business.

- The system of measures should provide a succinct overview of an organization's performance.

- The performance measures should be multi-dimensional.

- The performance measurement matrix (PMM) provides comprehensive mapping.

- The performance measures should be integrated across the organization's functions and through its hierarchy.

- The performance measurement system can provide data for monitoring past performance and planning future performance. It implies the measures should measure both results and the drivers of them.

During last two decades growing attention has been also paid to the study of performance measurement systems as instruments for effective strategy implementation. Most surveys of performance measurement have focused on its role relating to translation of strategy into action, confirming that PM systems are particularly instrumental in this regard (Kaplan, Norton, 1996, Butler, 1997, Simons, 2000).

\section{Analysis of Performance Measurement Systems: Strong and Weak Points}

The most widely adopted PM systems are the Balanced Scorecard (Kaplan and Norton 1996) and the EFQM Business Excellence Model (EFQM, 1999). They both provide a structured approach for identifying improvement opportunities and threats, and translating companies' strategy in achievable goals, targets and specific tasks. In contrast to these systems, competing techniques were introduced, such as: The Performance Measurement Matrix (Keegan et al., 1989), SMART Performance Pyramid (Lynch, Cross, 1991), Performance Prism (Neely, Adams et al. 2001), Kanji Business Excellence Performance System (Kanji, 2002), Theory of constraints (Goldratt, 1990), among others.

On the other hand, to date, researchers have not adopted a universally accepted bestpractice due to the following requirements on PM (Gomes et al., 2004):

- must reflect relevant non-financial information based on key success factors of each business (Clarke, 1995);

- should be implemented as a means of translating strategy and monitoring business results (Grady, 1991); must be aligned and fit within a strategic system (Drucker, 1990),

- should be based on organizational objectives, critical success factors, and 
customer needs and should monitor both financial and non- financial aspects (Manoochehri, 1999);

- must accordingly change dynamically with the strategy (Bhimani, 1993);

- must make a link to reward systems (Tsang et al., 1999).

The following text provides an overview of the more common and most cited approaches to performance measurement that tries to investigate whether they have in fact addressed the limitations of traditional ways of measuring performance. Based on different characteristics and premises, each system has its benefits and limitations in the aspects of performance measurement. Analysis of these benefits and limitations are based on the literature review of abovementioned case studies and other resources (Podobnik (2007); Hudson, Smart, Bourne (2001); Pun, White (2005); Schwartz (2005); Tangen (2004); Yaghoubi, Bandeii, Moloudi (2010)). The most significant are clearly summarized in tables.

\section{Balanced Scorecard}

The BSC was developed in the early 1990's by Robert Kaplan, an accounting professor at Harvard Business School, and David Norton, president of Renaissance Solutions, Inc., an international consulting firm specializing in performance measurement and organizational renewal. The BSC is a tool used for describing, implementing and managing strategy at all levels in the organization. The BSC assists organizations in developing a better performance measurement system than one solely dependent on financial measures (Schwartz, 2005). In other words BSC fulfil three basic functions in organization: the measurement system, the system of strategic management and the tool for communication.

The core of the method is the elaboration and the implementation of a vision and the strategy of an organization into fixed targets and intelligible set of financial and nonfinancial performance indicators. The introduction of BSC means that the goals, the indicators and the strategic actions are assigned to a concrete point of view or the so-called perspectives (Horvath \& Partners, 2004, p. 10).

The general BSC model is looking at organizations from four strategic perspectives: the financial, the customer, the internal processes, and the learning and growth, all of them need to be balanced. The balance means the equability between the short-term and the long-term goals; required inputs and outputs; internal and external performance factors; and financial and nonfinancial indicators (Striteska, 2010). The choice of these perspectives is not random; it offers a transparent view of interconnection between the organization's success and the drivers of performance. Thus, they built a flexible system within the established strategy. 
Table 1: Balanced Scorecard

\begin{tabular}{|c|c|}
\hline & Enumeration: \\
\hline STRONG POINTS & $\begin{array}{l}\text { - clarity of vision and strategy adopted } \\
\text { - consistent monitoring of strategy } \\
\text { - concentration on strategic, in the competition environment critical } \\
\text { business objectives } \\
\text { - cross-disciplinary and hierarchy traversing communication process } \\
\text { integration of performance measures for operational objectives at an } \\
\text { - cappropriate level }\end{array}$ \\
\hline WEAK POINTS & $\begin{array}{l}\text { - does not express the interests of all stakeholders } \\
\text { - lack of long-term commitment and leadership for management } \\
\text { - } \quad \text { too many/few metrics - development of unattainable metrics } \\
\text { - lack of employee awareness or a failure to communicate information to all } \\
\text { - } \text { employees } \\
\text { - } \quad \text { no relationships' quantification } \\
\text { - inappropriate to benchmarking }\end{array}$ \\
\hline
\end{tabular}

\section{EFQM}

The EFQM Excellence Model was generated in 1991 and introduced him the European Foundation for Quality Management (EFQM) with the support of EOQ, the European Organization for Quality, and the European Commission. The EFQM Excellence Model is a non-prescriptive system, proposed to help organizations to assess their progress to excellence and continuous improvement, and is based on their eight fundamental concepts of excellence: results orientation; people development and involvement; customer focus; continuous learning, innovation and improvement; leadership and constancy of purpose; partnership development; management by process and facts; and public responsibility.

These concepts are expressed and specified in nine criteria that are divided into five key implementation factors or enablers and four results in order to measure excellence (Calvo-Mora et al., 2005). Among the five enabling activities the model included: leadership, people, policy \& strategy, partnership \& resources and processes. The enablers drive the four sets of results: people, customer, society and key performance results. Each criterion consists of sub-criterions (totally thirty-two) that are supplemented by a list of typical areas which should be addressed. The core of the EFQM model is the RADAR methodology which is cyclical and continuous. The methodology consist of five steps: determine required results, plan and develop approaches, deploy approaches, asses and review achieved results. Thus designed model is used as a self-assessment tool, which enables a comprehensive, systematic and regular review of an organization's activities and results.

The Model is currently used by thousands of organizations mainly throughout Europe, such as firms, health institutions, schools, public safety services and local government institutions, among others. It provides organizations with common management terminology and tools, thus facilitating the sharing of best practices among organizations of different sectors (Ray, 2003). 
Table 2: EFQM Excellence Model

\begin{tabular}{|c|c|}
\hline & Enumeration: \\
\hline STRONG POINTS & $\begin{array}{l}\text { - } \text { systematic and non-prescription model } \\
\text { - } \quad \text { using of self-assessment approach in order to organization excellence } \\
\text { - } \\
\text { - } \quad \text { recognition of strong and weakness points of organization } \\
\text { - } \quad \text { consist of criteria hierarchy } \\
\text { - } \quad \text { allow shortlist of indicators based on "Good example" of practice } \\
\text { - } \quad \text { creating conditions for comparative analysis of business processes with } \\
\text { - } \quad \text { external business } \\
\end{array}$ \\
\hline WEAK POINTS & $\begin{array}{l}\text { - no focus / priorities - no links } \\
\text { - criteria are not specific within the company - no possibility for } \\
\text { differentiation } \\
\text { - is not strategic management tool (systematic setting and achieving } \\
\text { goals) - therefore, is not instrument for strategy implementation } \\
\text { - is not suitable for enterprise communication } \\
\text { - tendency to bureaucracy } \\
\text { - did not give quidelines how to design and conduct effective } \\
\text { performance measurement }\end{array}$ \\
\hline
\end{tabular}

\section{The Performance Measurement Matrix}

The performance measurement matrix was first-time presented in 1989 by Keegan et al. and is able to integrate different dimensions of performance, and employs generic terms such as internal, external, cost, and non-cost. The strength of the performance measurement matrix lies in the way it seeks to integrate different classes of business performance financial and non-financial, internal and external. (Neely et al., 2000) Second in order Fitzgerald et al. (1991) developed modified system of the performance measurement matrix called Results and Determinant. The Fitzgeralds alternative tries to overcome the criticism of matrix that is not as well packaged as the balanced scorecard and does not make explicit the links between the different dimensions of business performance, which is arguably one of the greatest strengths of Kaplan and Norton's balanced scorecard (Neely et al., 2000). The performance measurement matrix from Fitzgerald is based on the key assumption that there are two basic types of performance measure in any organization, those that relate to results (competitiveness, financial performance), and those that focus on the determinants of the results (quality, flexibility, resource utilization and innovation). The explanation of this distinction is that it highlights the fact that the results obtained are a function of past business performance with regard to specific determinants, i.e. results are lagging indicators, whereas determinants are leading indicators (Neely et al., 2000). 
Table 3: Performance Measurement Matrix

\begin{tabular}{|c|c|}
\hline & Enumeration: \\
\hline STRONG POINTS & $\begin{array}{l}\text { - } \quad \text { specifies, in reasonable detail, what the measures should look like } \\
\text { - } \quad \text { provides a useful development process }\end{array}$ \\
\hline WEAK POINTS & $\begin{array}{l}\text { - does not include customers or human resources as dimensions of } \\
\text { performance } \\
\text { - can not give a truly balanced view of performance. } \\
\text { - consists of several different tools - is potentially complicated to } \\
\text { - } \text { understand and use } \\
\text { fails to provide an explicit process for developing the PM model }\end{array}$ \\
\hline
\end{tabular}

\section{The SMART Performance Pyramid}

Another system is the SMART Performance Pyramid, i.e. the SMART system, which was proposed by Cross and Lynch (1992). The primary aim of the performance pyramid is to connect through organization's strategy with its operations by translating objectives from the top down (based on customer priorities) and measures from the bottom up (Tangen, 2004). The Performance Pyramid contains four levels of objectives that affect the organization's external effectiveness and simultaneously its internal efficiency. At the first level of pyramid is defined an overall corporate vision, which is then divided into individual business unit objectives. At the second-level of pyramid are set short-term targets (e.g. of cash flow and profitability) and long-term goals of growth and market position (e.g. market, financial). The third level contains day-to-day operational measures (e.g. customer satisfaction, flexibility, productivity). Last level includes four key indicators of performance measures: quality, delivery, cycle time, waste.

Table 4: SMART Performance Pyramid

\begin{tabular}{|c|c|}
\hline & Enumeration: \\
\hline STRONG POINTS & $\begin{array}{l}\text { - attempt to integrate corporate objectives with operational performance } \\
\text { indicators } \\
\text { - } \quad \text { manage PM strategically }\end{array}$ \\
\hline WEAK POINTS & $\begin{array}{l}\text { - does not provide any mechanism to identify key performance } \\
\text { indicators } \\
\text { - fails to specify the form of the measures } \\
\text { - does not explicitly integrate the concept of continuous improvement }\end{array}$ \\
\hline
\end{tabular}

\section{The Performance Prism}

The Performance Prism (PP) is one of the younger conceptual systems and is considered as a second-generation PM system. This system was developed by a team of experienced researchers and consultants in PM area Neely, Adams, and Kennerley (2001). They described a comprehensive measurement system that addresses the key business issues to which a wide variety of organisations, profit and not- for-profit, will be able to relate (Neely, Adams, Crowe, 2001). Performance prism builds on the strengths of existing measurement system on shareholder value and brings innovation based on free premises. In the first place, the organizations should think about the wants and needs of all of their key stakeholders as well as how to deliver value to each of them. Secondly, organizations have to harmonize and integrate strategies, processes, and capabilities in order to deliver real value to 
its stakeholders. Thirdly, the relationship between organizations and their stakeholders is reciprocal - stakeholders expect the fulfillment of their wants and needs on the other hand they have to contribute to organizations (Wu, 2009). Therefore the Performance Prism consists of five interrelated facets, i.e. Stakeholder satisfaction, Strategies, Processes, Capabilities and Stakeholder contributions.
Another interesting point of PP is that it is not a prescriptive measurement system. According to PP the performance measurement should not be derived from the strategy: instead, "strategies should be put in place to ensure the wants and needs of the stakeholders are satisfied" (Neely et al. 2001). It is tool that helps management teams to think about vital questions and strategies to address them.

Table 5: Performance Prism

\begin{tabular}{|c|c|}
\hline & Enumeration: \\
\hline STRONG POINTS & 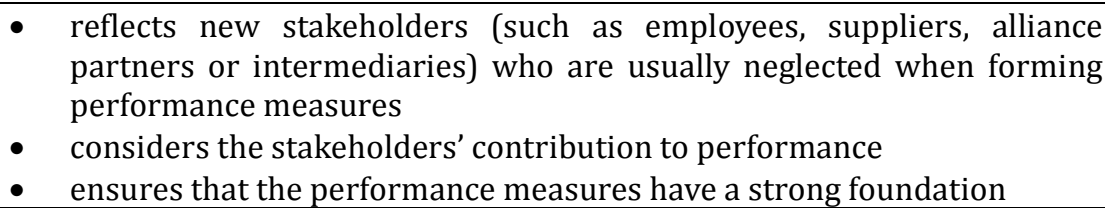 \\
\hline WEAK POINTS & $\begin{array}{l}\text { - offers little about how the performance measures are going to be } \\
\text { implemented } \\
\text { - } \text { some measures are not effective in practice } \\
\text { short of logic among the measures, no sufficient link between the } \\
\text { results and drivers } \\
\text { no consideration is given to the existing PMSs that companies may have } \\
\text { in place }\end{array}$ \\
\hline
\end{tabular}

Kanji Business Excellence Measurement System (KBEMS)

Kanji Business Excellence Measurement System (hereafter KBEMS) is second from younger conceptual systems. This system consists from Excellence Model (KBEM) and Kanji Business Scorecard (KBS) and is based on Critical Success Factors (CSFs), which correspond to the drivers of performance. Author's name Kanji indicates the name of the system itself. The KBEMS is formed by Part A and Part B of the Performance Measurement System and these parts should be applied simultaneously always, since they form a single and complementary view of organizational performance. KBEM is intended for the measurement of performance from the internal stakeholders' point of view, whereas the KBS evaluates the performance from the external stakeholder' perspective. Afterwards internal and external scores are incorporated to calculate the final organizational performance excellence index (OPI) that provides an aggregate measure of the organizations excellence in managing all the CSFs. Kanji's Performance Measurement Model includes ten items in Part A (leadership, delight the customer, customer focus, management by fact, process improvement, people-based management, people performance, continuous improvement, continuous improvement culture, performance excellence A) and five items in Part B (organisational values, process excellence, delight the stakeholders, performance excellence B). It follows a short description of each criterion (Kanji, 2002). 
Table 6: KBEMS

\begin{tabular}{|c|l|}
\hline & \multicolumn{1}{|c|}{ Enumeration: } \\
\hline STRONG POINTS & $\begin{array}{l}\text { multi-perspective view of performance, combining financial and non- } \\
\text { financial measures and the assessment of different stakeholders }\end{array}$ \\
& $\begin{array}{l}\text { is linked to the organization's values and strategies and based on the } \\
\text { CSFs }\end{array}$ \\
& $\begin{array}{l}\text { is a generic and universal model and calculates overall indices, } \\
\text { comparisons can be made } \\
\text { highlights improvement opportunities and suggests some improvement } \\
\text { strategies for the best possible use of the organization's resources } \\
\text { can help organizations to develop, } \\
\text { Cascade and implement an organization's strategy }\end{array}$ \\
\hline WEAK POINTS & $\begin{array}{l}\text { is primarily designed for senior managers to provide them with an } \\
\text { overall view of performance } \\
\text { does not offer explicit guidance on how to develop and implement a PM } \\
\text { system effectively }\end{array}$ \\
\hline
\end{tabular}

\section{Theory of Constraints (TOC)}

The TOC has changed over the past 20 years from a production scheduling technique to a systems methodology which is primarily concerned with managing change. Original goal of TOC, which was first used in 1980, was set out to devise a systematic approach to identifying what was preventing a company from achieving its goal of making money for its owners. TOC helping set of tools that guide the user to find answers to the basic questions relating to change, namely: What to change? What to change to? How to cause the change? Goldratt's TOC states that the overall performance of an organisation is limited by its weakest link. He mentions that if an organisation wants to improve its performance, the first step must be to identify the system's weakest link, or constraint. Hence TOC can be used also for performance measurement. The TOC's "five steps of focusing" are conducted in the following way (Goldratt, 1990): identify the system's constraint(s); decide how to exploit the system's constraint(s), subordinate everything else to the above decisions, elevate the system's constraint(s), and when a constraint is broken, go back to the first step. The TOC tool contains three global performance measures, which are used for assessing a business organisation's and ability to obtain the goal (i.e. making money). These global measures represent net profit, ROI and cash flow.

Table 7: Theory of Constraints

\begin{tabular}{|c|c|}
\hline & Enumeration: \\
\hline STRONG POINTS & $\begin{array}{l}\text { - } \begin{array}{l}\text { provides focus in a information overload } \\
\text { - } \\
\text { compremance measures within TOC are both easy to access and easy to }\end{array} \\
\end{array}$ \\
\hline WEAK POINTS & $\begin{array}{l}\text { - is far from being a complete PM system } \\
\text { - TOC simplifies the reality a little too far, since TOC assumes that there always is } \\
\text { a legible constraint in the system, which is not necessarily true }\end{array}$ \\
\hline
\end{tabular}

\section{Conclusions}

The presented review shows that the context within which performance measurement is used is changing as well as how selected approaches to performance management try to solve the limitations of the traditional way of measuring performance. The balanced 
Journal of Organizational Management Studies 10

scorecard and the performance pyramid are two excellent illustrations to strategically driven PMFs. Organizations can use them to clarify goals, define performance objectives and communicate selected strategies. Contrary, non-prescriptive self-assessment EFQM is more suitable for benchmarking. The younger systems like Performance Prism or KBEM build on the strengths of previously developed systems (namely BSC) and address their shortcomings. Their main purpose is to respond to changing priorities in the so-called "new economy“.

Nevertheless how performed analysis confirms, every conceptual PM system has some benefits and several weaknesses. According to Tangen (2004) the most common limitation being that little guidance is given for the actual selection and implementation of the measures. In general, the above mentioned systems have a clear and extensive theoretical background, but do not provide guidance on how a company should design its specific PMS as well as seldom help with the practical realisation of specific measures at an operational level. Because the environment develop dynamically, the strategies of organisations need to be change over time and when a strategy changes, some performance measures must change too. There is therefore a need for flexibility in the PM systems. Some scholars argue that than develop another PM system, it is more reasonable define main features, processes and roles of PM systems and on their bases each organisation can start to create and implement its unique and specific system.

Unfortunately, since a dominant theory has not been developed, most companies simply continue with what they've used in the past, rarely deviating from their established practices $(\mathrm{Wu}, 2009)$. Therefore, further research to explore how the conceptual frameworks can be translated and tailored to fulfil the unique measurement needs of a specific company, especially at the operational level, is needed.

\section{Acknowledgment}

This article was prepared in relation to the project IGA UPCE SGS - SGFES03/2012.

\section{References}

Appelbaum, S. H., Nadeau, D. \& Cyr, M. (2008). "Performance Evaluation in a Matrix Organization: A Case Study (Part Two)," Industrial and Commercial Training, 40.Â 6. 295-299.

Bhimani, A. (1993). "Performance Measures in Uk Manufacturing Companies: The State of Play," in Management Accounting, Vol. 71 No. 11, Pp.20-2.

Bititci, U. S., Carrie, A. S. \& McDevitt, L. (1997). "Integrated Performance Measurement Systems: A Development Guide," in International Journal of Operations \& Production Management, Vol. 17 No. 5. Pp. 522-35.

Butler, A. Letza, S. R. \& Neale, B. (1997). "Linking the Balanced Scorecard to Strategy," In Long Range Planning, 30(2). Pp. 242 - 253.

Calvo-Mora, A., Leal, A. \& Rolda, J. L. (2005). "Relationships Between the Efqm Model criteria: a study in Spanish universities," Total Quality Management, Vol. 16, No. 6, S. 741-770. Issn 1478-3363.

Clarke, P. (1995). 'Non-Financial Measures of Performance in Management,' in Accountancy Ireland, Vol. 27 No.2, Pp.22-4.

Conradie, J. \& Schutte, H. (2003). "Are Performance Measurements Relevant to Municipalities?," in Accountancy Sa; Mar. Accounting \& Tax Periodicals. Pp.17-18.

Cumby, J. \& Conrod, J. (2001). “Non-Financial Performance Measures in the Canadian Biotechnology Industry," in Journal of Intellectual Capital, 2(3): 261. 
Drucker, P. E. (1990). "The Emerging Theory of Manufacturing," in Harvard Business Review, Pp.94-102.

EFQM (2003). 'Introducing Excellence Brussels: European Foundation for Quality Management,'

Epstein, M. J. \& Manzoni, J. F. (1997). The Balanced Scorecard and Tableau De Board: A Global Perspective on Translating Strategy into Action, in Management Accounting (August). Pp. 28-36.

Goldratt, E. M. (1990). What Is This Thing Called The Theory Of Constraints? North River.

Gomes, C. F., Yasin, M. M. \& Lisboa, J. V. (2004). "A Literature Review of Manufacturing Performance Measures and Measurement in an Organizational Context: A Framework and Direction for Future Research," in Journal of Manufacturing. Technology Management, 15(6): 511.

Grady, M. W. (1991). 'Performance Measurement: Implementing Strategy,' in Management Accounting, Vol. 72, No. 12, Pp. 49-53.

Hudson, M., Smart, A. \& Bourne, M. (2001). "Theory and Practice in SME Performance Measurement Systems," International Journal of Operations \& Production Management, Vol. 21, No. 8, S. Pp. 1096-1115. Issn 0144-3577.

Ittner, C. D. \& Larcker, D. F. (2001). "Assessing Empirical Research in Managerial Accounting: A Value-Based Management Perspective," in Journal of Accounting Research, 40 (3). Pp. 711-727.

Kanji, G. K. (2002). "Performance Measurement System," in Total Quality Management, Vol. 13, No. 5, Pp. 715-728.

Kaplan, R. S. \& Norton, D. P. (1996). The Balanced Scorecard: Translating Strategy into Action, Boston. Ma: Harvard Business School Press.
Kennerley, M., Adams, C. \& Neely, A. (2002). The Performance Prism: The Scorecard for Measuring and Managing Stakeholder Relationships, Financial Times/Prentice Hall, London.

Kennerley, M. \& Neely, A. (2002). “A Framework of the Factors Affecting the Evolution of Performance Measurement Systems," in International Journal of Operations \& Production Management, 22(11): 1222-1245.

Kloot, L. \& Martin, J. (2000). "Strategic Performance Management: A Balanced Approach to Performance Management Issues in Local Government," in Management Accounting Research, Vol. 11, Pp. 231-251.

Lynch, R. L. \& Cross, K. F. (1991). Measure Up! Yardsticks for Continuous Improvement, Basilblackwell, Oxford.

Mabin, V. (1990). "Goldratt's Theory of Constraints "Thinking Processes": A Systems Methodology Linking Soft With Hard,"

Manoochehri, G. (1999). "The Road to Manufacturing Excellence: Using Performance Measures to Become WorldClass," in Industrial Management, Pp.7-13.

Marques, A. I., Rosa, M. J., Soares, P., Santos, R., Mota, J. \& Carvalho, J. (2011). "Evaluation of Physical Activity Programmes for Elderly People - A Descriptive Study Using the Efqm' Criteria," Bmc Public Health, 11:123, S. 1-16. Available From www: <http://www.biomedcentral.com/14712458/11/123>. Issn 1471-2458.

Meyer, M. W. (2002). Rethinking Performance Measurement: Beyond the Balanced Scorecard, in Cambridge University Press, Pp. 81-113.

Moullin, M. (2003). 'Defining Performance Measurement,' in Perspectives on Performance, 2(2):3. 
Nabitz, U., Severens, P., van den Brink, W. \& Jansen, P. (2001). "Improving the Efqm Model: An Empirical Study on Model Development and Theory Building Using Concept Mapping," Total Quality Management, Vol. 12, No. 1, S. 69-81. Issn 0954-4127.

Nanni, A. J., Dixon, J. R. \& Vollmann, T. E. (1992). 'Integrated Performance Measurement: Management Accounting to Support the New Manufacturing Realities,' in Journal of Management Accounting Research, 4: 1-19.

Neely, A., Adams, C. \& Crowe, P. (2001). "The Performance Prism in Practice," Measuring Business Excellence, Vol. 5, 2, S. Pp. 6 - 12. Issn 1368-3047. Press, Croton-on-Hudson, $\mathrm{Ny}$.

Neely, A., Adams, C. \& Kennerley, M. (2002). The Performance Prism: The Scorecard for Measuring and Managing Business Success, London: Prentice.

Othman, R. Domil, A. K. A., Senik, Z. C., Abdullah, N. L. \& Hamzah, N. (2006). "A Case Study of Balanced Scorecard Implementation in a Malaysian Company," Journal of AsiaPacific Business, Vol. 7, No. 2, S. 55-72.

Plant, T. (2006). 'The Performance Measurement Paradox in Local Government Management,' in Pm. Public Management, May. Vol. 88, No. 4, Pp. 16-20.

Podobnik, D. (2007). 'The European Model of Business Excellence and a Balanced Indicator System within the Model of Integral Management,' Pregledni Znanstveni Članki. Št. 5-6, S. 40-52.

Pun, F. K. \& White, A. S. (2005). “A Performance Measurement Paradigma for Integrating Strategy Formulation: A Review of Systems and Frameworks," International Journal of Management Reviews, Vol. 7, No. 1, Pp. 49-71.
Ray, P. K. (2003). Integrated Management from E-Business Perspective: Concepts, Architectures, and Methodologies, in Network and Systems Management Series. Edited By: M. Malek. New York: Kluwer Academic/Plenum Publishers.

Rusell, S. (2000). "ISO 9000: 2000 and the EFQM Excellence Model: Competition or Cooperation?," Total Quality Management, 11, Pp. 657-665.

Sadeh, E. \& Arumugam, V. Ch. (2010). "Interrelationships among EFQM Excellence Criteria in Iranian Industrial Smes," European Journal of Economics, Finance and Administrative Sciences, Issue 19, S. 155-167. Issn 1450-2887.

Schwartz, J. (2005). "The Balanced Scorecard Versus Total Quality Management: Which is Better for Your Organization?," Military Medicine, Vol. 170, S. 855 - 858.

Simons, R. (2000). Performance Measurement and Control Systems for Implementing Strategy: Texts and Cases, London: Prentice-Hall, 792 P. Isbn 9780132340069.

Stř́iteská, M. (2010). 'Role Nefinančních Měřítek Ve Strategickém Řízení,' In Manažerská Etika. Díl 8, Inspirace Pro 21.Století. 1.Vyd. Zlín: Univerzita Tomáše Bati Ve Zlíně, 5 S. Isbn 978-80-7318-941-9.

Tangen, S. (2004). "Performance Measurement: From Philosophy to Practice," International Journal of Productivity and Performance Management, Vol. 53, No. 8, Pp. 726-737. Issn 1741-0401.

Tsang, A. H. C., Jardine, A. K. S. \& Kolodny, H. (1999). "Measuring Maintenance Performance: A Holistic Approach," in International Journal of Operations \& Production Management, Vol. 19 No. 7, Pp. 691-2. 
13 Journal of Organizational Management Studies

Webber, A. M. (2000). "New Math for a New Economy," Fast Company, 31: 214.

Wu, D. (2009). "Measuring Performance in Small and Medium Enterprises in the Information \& Communication Technology Industry," Ph.D. Thesis. School of Management, Rmit University, February 2009.

Yaghoubi, N. M., Bandeii, M. \& Moloudi, J. (2011). "An Empirical Study of the Efqm Excellence Model in Iran," International Journal of Business and Management, Vol. 6, No. 5, S. 260-267. Issn 1833-3850. 